\title{
Original paper \\ Geometry of the Altenberg-Teplice Caldera revealed by the borehole and seismic data in its Czech part
}

\author{
Bedřich MLČOCH ${ }^{*}$, Zuzana SKÁCELOVÁ2 \\ ${ }^{1}$ Czech Geological Survey, Klárov 3, 11821 Prague 1, Czech Republic; bedřich.mlčoch@geology.cz \\ ${ }^{2}$ Czech Geological Survey, Erbenova 348, 79001 Jesenik, Czech Republic \\ * Corresponding author
}

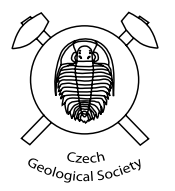

The Altenberg-Teplice Caldera (ATC) in the eastern Krušné hory Mts./Erzgebirge (Czech Republic, Germany) is the largest centre of Late Palaeozoic acid volcanism in the Bohemian Massif. Previous studies were focused mainly on its exposed part in the north, as the southern part is covered by Tertiary sediments. Borehole data, geological mapping and geophysical survey enabled to gain a new image of its areal and vertical extent and to construct a digital model of individual geological units. The evaluation of the Czech Geological Survey - Geofond borehole database and 3D modelling of the crystalline relief and of the rhyolite complex enabled to reconstruct the geometry of the Czech part of the ATC.

Keywords: Saxothuringian Zone, Eastern Krušné hory Mts./Erzgebirge Volcano-Plutonic Complex, Altenberg-Teplice Caldera, borehole, seismic data, erosion level

Received: 21 May 2010; accepted: 9 September 2010; handling editor: M. Štemprok

\section{Introduction}

Calderas belong to important volcanic structures and many recent studies deal with their experimental analogue modelling, anatomy and development (e.g. Walter and Troll 2001; Troll et al. 2002; Cole et al. 2005; Holohan at al. 2008). An uplift and collapse of the caldera shape its structure and cause deformations with the fault systems specific for each region. One of the possible approaches is to focus on the geometry of the caldera structure revealed by the analysis of a digital elevation model (Spinks at al. 2005) and by geophysics (in particular the seismic and gravity data). These methods enable to interpret the position of the faults and decipher the tectonic development. In particular, earlier volcanic structures are not easy to reconstruct without the aid of the accurate digital elevation model of geological units and the knowledge of their geological development.

The Altenberg-Teplice Caldera (ATC) in the eastern Krušné hory Mts./Erzgebirge (Czech Republic and Germany) is thought to be a giant collapse caldera, where the eruptions of rhyolitic lavas and ignimbrites of Carboniferous age were accompanied by granite and granite porphyry (microgranite) intrusions (Fig. 1). This volcano-plutonic complex crops out only in its northern part; further southwards it is covered by the sediments of the North Bohemian Basin. Moreover, a tectonically sunken block of the Saxothuringian crust (the Altenberg Block) occurs inside the ATC.

Moesta (1928) interpreted as the first this large volcanic and sub-volcanic complex as a relic of a Late Variscan caldera. Holub (1980) studied the petrography in the deep borehole B/Le 127 Ledvice and found out that the "quartz porphyries" actually corresponded to ignimbrites. Jiránek et al. (1987) summarized the results of previous detailed geological, petrological and geochemical studies in the Czech part of the Teplice rhyolite body. Benek (1991) described the ATC as a palaeo-caldera of trapdoor type.

The assessment of the actual size of the caldera has been hampered by the fact that its southern part is covered by Cretaceous and Tertiary sediments. The recent evaluation of the boreholes that reached bedrock of the North Bohemian Basin with detailed geological mapping (Mlčoch ed. 1989) made it possible to define the probable extent of the caldera and also enabled the compilation of geological map of the crystalline basement (Fig.1 after Mlčoch 1994; Mlčoch ed. 2001). Seltmann and Schilka (1995) evaluated new geochemical and geochronological data giving thus significant information "about the role of volcanics in the petrogenetic and metallogenic evolution of this crustal unit". This was followed by a number of detailed geochemical studies concerned with the evolution of the ATC volcano-plutonic complex (e.g. Breiter 1997; Breiter et al. 2001; Müller and Seltmann 2002; Štemprok et al. 2003). The granites in the Krušné hory Mts./Erzgebirge have been divided traditionally into two major suites (Lange et al 1972); the Older Intrusive Complex (OIC) and the Younger Intrusive Complex (YIC). The results of dating and mutual relationships of Late Variscan magmatites of the eastern part of the Krušné hory Mts./Erzgebirge are summarized e.g. in the articles by Štemprok et al. (2003), Müller et al. (2005), Romer et al. 


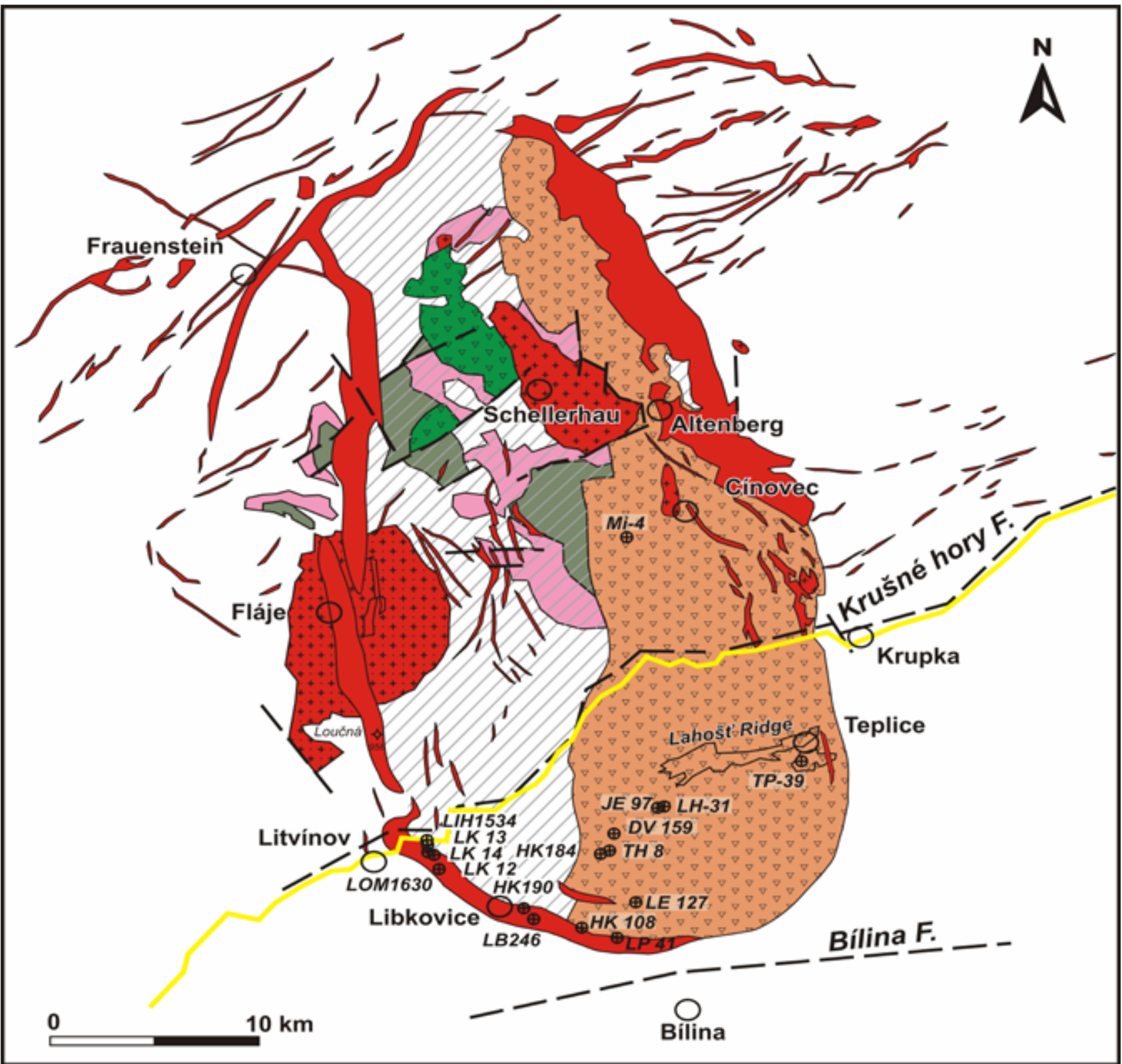

\section{Saxothuringian Zone:}

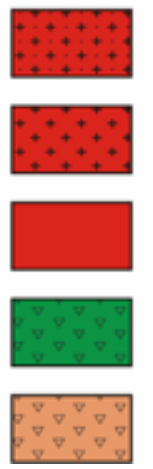

granites (OIC)

granites (YIC)

granite porphyry and

rhyolite dykes

Schönfeld Unit

Teplice rhyolite
Early Palaeozoic

(metabasites, phyllites)

orthogneiss underlying metabasites and phyllites

Saxothuringian

Crystalline Complex

\section{Altenberg Block}

\section{- - faults}

northern margin of the North Bohemian Basin

Fig. 1 Geological map of the Altenberg-Teplice Caldera area (after Mlčoch ed. 1989; Hoth et al. 1995) with the selected significant boreholes. 
(2007) and, most recently, by Förster and Romer (2010). The age determinations are problematic because there are only a few available geochronological data for the ATC, which differ considerably from each other according to different authors and/or dating methods.

\section{Geological setting}

Thick granite porphyry dykes referred to as the Altenberg-Frauenstein microgranite (Müller and Seltmann 2002) mark the caldera border from Frauenstein to Loučná in the west. They submerge further to the southeast under the sediments of the North Bohemian Basin and continue to the southern margin of the Teplice rhyolite body. The dykes also rim the eastern margin of the Teplice rhyolite (e.g. Altenberg dyke) and can be considered as a component of the caldera. The granite porphyry dykes, together with the Teplice rhyolite, form a giant elliptical structure $18 \times 35 \mathrm{~km}$ across (Fig. 1) of gravity trap-door character with the maximal subsidence in its southeastern part. The intrusion of marginal granite porphyry dykes marked the final phase of the ATC evolution, filling the ring faults. The Altenberg Block (the sunken roof pendant of the crystalline basement) is tilted to the east. Volcanic sequences in the hanging wall in the western part of the caldera underwent denudation. They are preserved only to limited extent in some places of the northern part of the Altenberg Block.

\subsection{Saxothuringian Zone - Saxothuringian Crystalline Complex - Altenberg Block}

The Altenberg Block represents a roof pendant covering the western part of the ATC. It consists predominantly of paragneisses belonging to the Saxothuringian Crystalline Complex. Due to the occurrence of remnants of low-grade Early Palaeozoic rocks, it was previously considered to be down-thrown relative to the surrounding area. Paragneisses, possibly at a rather deep erosion level, occur in the southern part of the Altenberg Block. A sharp tectonic boundary is evident between the orthogneisses of the Catherine Dome (in the $\mathrm{W}$ ) and the paragneisses of the Altenberg Block exposed in the southern part of the Loučná-Fláje dyke (Mlčoch ed. 1989; Hoth et al. 1995). The relics of nappes of low-grade Lower Palaeozoic rocks (phyllites and metabasites) are preserved in the central and northern parts of the ATC (Fig. 1). They occur also in the basement of the Schönfeld Unit and represent the upper structural level of the Saxothuringian Zone. Intercalations of intensively shear-deformed orthogneisses occur in their footwall. A comparable sequence was documented also in the valley of the Labe River near Litoměřice (Porta Bohemica), which is the southernmost outcrop of the Saxothuringian Zone at the contact with the Teplá-Barrandian Unit (Mlčoch 2003; Mlčoch and Konopásek 2010).

\subsection{Volcano-plutonic complex}

The Fláje granite Massif represents the pre-caldera intrusion (OIC in earlier terminology), while the CínovecKrupka and the Schellerhau granite massifs, along with several small granite intrusions, belong to the younger magmatic suite (considered as YIC). The latter intrude the Teplice rhyolite (Chrt and Malásek 1984; Novák et al. 1991). The Fláje granite Massif at the western margin of the ATC crops out in an area of $7 \times 9 \mathrm{~km}$ and is composed of two-mica and biotite granites. It reaches a depth of $9 \mathrm{~km}$ as shown by the reflection seismic data on the profile MVE-90 (DEKORP Research Group 1994).

The deep borehole Mi-4 (Mikulov) enabled to interpret the volcanic sequences of the Teplice rhyolite and provided lithogeochemical data presented by Breiter et al. (2001). These authors correlated dacites and intercalated sedimentary beds in the lower part of the Czech volcanic sequences with the Schönfeld Unit in Germany. The Teplice rhyolite body in the eastern ATC represents the most extensive outcrop of volcanic rocks (Fig. 1). In the basement of the North Bohemian Basin it continues as far to the Bílina river valley. The eastern margin of the Teplice rhyolite body is subvertical, rimmed by the Altenberg granite porphyry (microgranite) dyke. At the western margin the Teplice rhyolite and the Schönfeld Unit abut on the Altenberg Block at an angle of approximately $20-40^{\circ}$. The Carboniferous sediments in the Schönfeld Unit show the same dip. The maximal thickness of the Teplice rhyolite determined in the borehole TP-39 near Teplice is $1033 \mathrm{~m}$. The oldest sequences, i. e. the basal rhyolite and dacite, are found in the northern and middle parts (a distinct belt on the western margin of the Teplice rhyolite body) of the ATC. The rhyolites in the southern part belong to the youngest volcanic phase. Sporadic occurrences of dacite (older sequence) below the Teplice rhyolite were determined in the borehole LH-31 (Mlčoch ed. 2001) southwest of Teplice (Fig. 1). In the north of the caldera, a deeper level of the volcanic sequences was probably exposed by erosion, compared with its southern part.

Different trends are observed in the dykes inside and outside the ATC. Inside the caldera, the granite porphyry dykes fill the approximately NNW-SSE to NW-SE oriented faults, which originated during the gravity collapse. In Czechia, these dominate the central part of the Altenberg Block and in the Teplice rhyolite body.

Outside-the-caldera dyke swarms predominantly trend ENE-WSW to NE-SW and are generally perpendicular 




Fig. 2 Location of the boreholes and seismic profiles (crosses - surface of the crystalline complex, circles - surface of the Teplice rhyolite).

to the caldera's elongation. They are concentrated into several dyke swarms, which do not continue into the interior of the caldera. Rhyolitic dykes (Sayda-Berggiesshübel swarm) are most frequent at the northern margin of the caldera. Second large dyke swarm occurs in the Czech part of the eastern Krušné hory Mts./Erzgebirge. The origin of the dykes west of the ATC can be linked with the volcanic activity also, e.g. dykes between Hora Svaté Kateřiny and Steinbach (see Hoth et al. 1995).

\section{Methods}

The geometry of the Czech part of the ATC was reconstructed mainly from the borehole data, the field relations (detailed geological mapping at 1:25000 scale, Mlčoch ed. 1989; Jiránek ed. 1991; Schovánek et al. 2004) and the geophysical data (Fig. 2). The latter include seismic reflection data used for the determination of the depth of the contact plane between the sediments and the Teplice rhyolite on the one hand, and the vertical extent of the crystalline complex on the other. A digital elevation model of the ATC volcano-plutonic complex and of the crystalline basement below the sedimentary cover of the North Bohemian Basin was constructed using the re-evaluated borehole database of the Czech Geological Survey-Geofond (https://www.geofond.cz/mapsphere/ EEARTH/) and other sources (mining companies). In total we have utilized 2066 boreholes for the 3D mod- elling ( 727 boreholes for the Teplice rhyolite, and 27 boreholes for the crystalline relief in the basement of the rhyolite). All data were re-processed and checked for coordinates, depth and rock type. The surface of the ATC and of the crystalline relief was defined in each borehole (altitude, rock type, geological unit) and filed into the database. We also used the information on the hidden granite massif (proved by 21 boreholes) in the eastern part of the ATC. Lastly, data from the previous studies and available as a contour map (Chrt and Malásek 1984, Malásek ed 1987) were also utilized. The final digital elevation model for the study area was constructed by the combination of the modelled subsurface crystalline relief and Teplice rhyolite from boreholes and outcrops. The present-day relief was digitised from contour lines with an interval of $5 \mathrm{~m}$.

The Surfer software by the Golden Software Inc. was used for the 3D modelling. The XYZ data of the final 3D model were interpolated by kriging into a regular grid with a spacing of $100 \times 100 \mathrm{~m}$.

\section{Results}

\subsection{Seismic data}

Seismic refraction survey (common-depth-point) was carried out in the North Bohemian Basin district in the years 1981 and 1983 (Jihlavec et al. 1983, 1984) as a part of the geological mapping and exploration for brown coal deposits (Figs 2 and 3). In total three Slalom line profiles

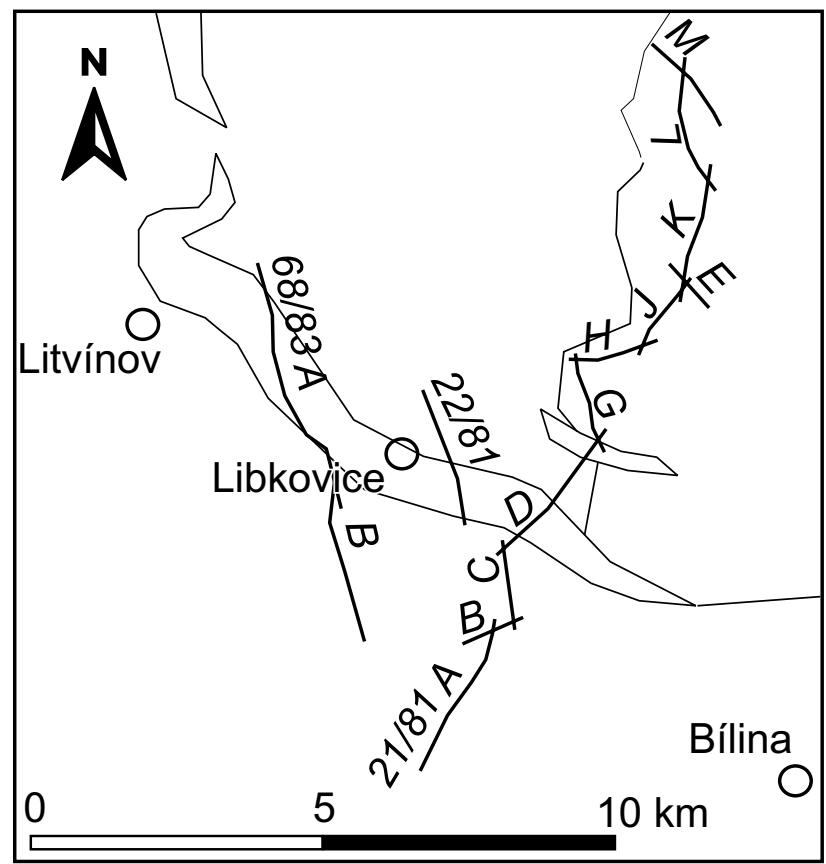

Fig. 3 Location of seismic profiles. 


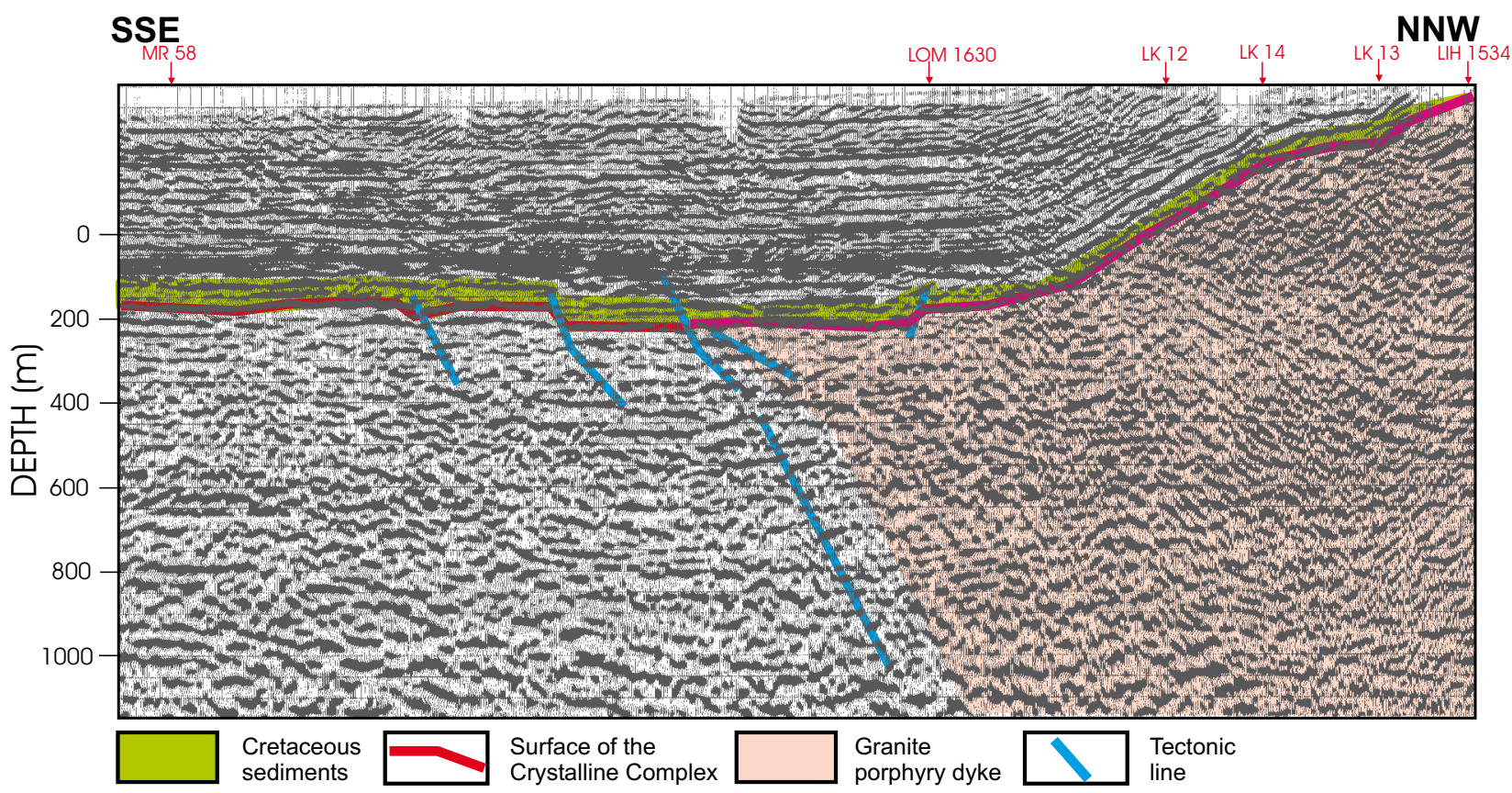

Fig. 4 Depth reflection seismic section $68 / 83$ and its interpretation.

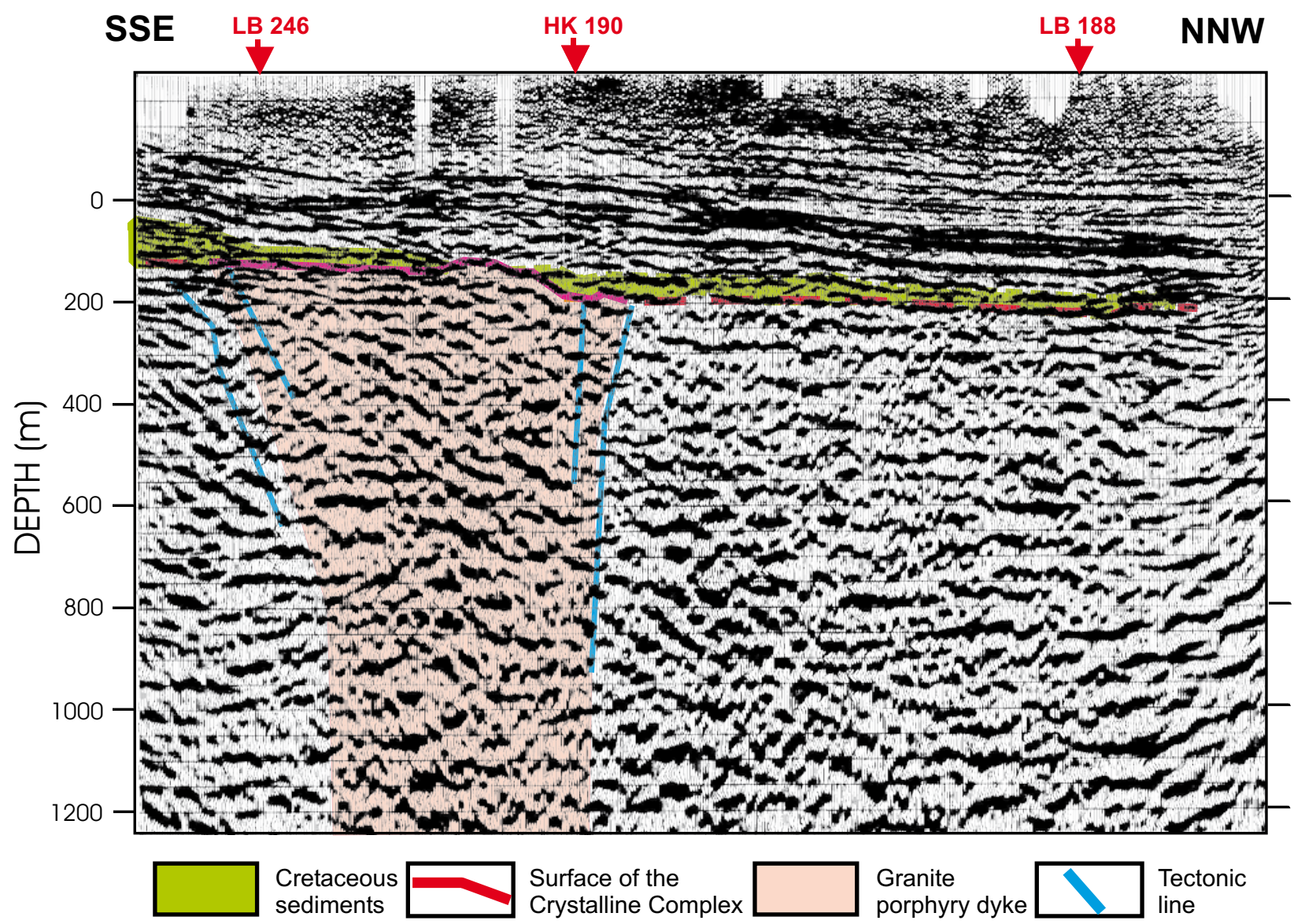

Fig. 5 Depth reflection seismic section 22/81 and its interpretation. 


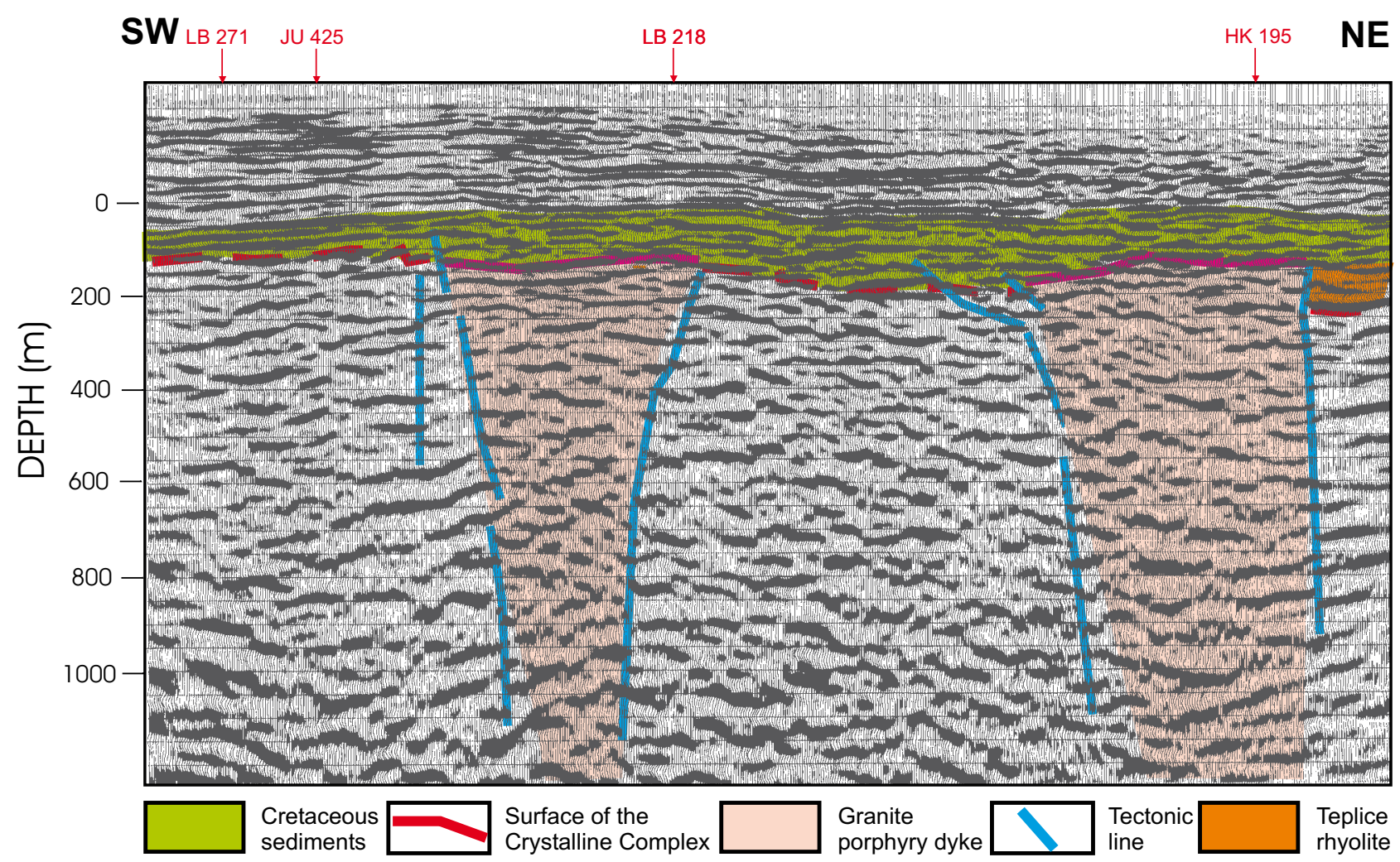

Fig. 6 Depth reflection seismic section $21 \mathrm{D} / 81$ and its interpretation.

were measured: 22/81, 68/83 and 21/81, which were combined from 10 sections. The quality of the primary data is good, so that they could be used for the study of the tectono-structural relations in the Tertiary sedimentary basin using new software (Rajchl et al. 2003).

The image and interpretation of the individual reflection interfaces were employed in this study, above all, for the 3D modelling of the crystalline complex and the Teplice rhyolite concealed below the Tertiary and Cretaceous sediments. The depth data acquired from seismic sections were correlated with new borehole logs and used for geological interpretation of the crystalline basement (Mlčoch 1994). Thus the reflection interfaces could be interpreted with a great accuracy along the entire profile length, including radial tectonic structures. The granite porphyry dyke documented between Litvínov and Libkovice (Mlčoch ed. 1989) is characterized by the changes of amplitude and frequency of seismic signal and area represented by missing reflections. Previous interpretation (Rajchl et al. 2003) assumed a presence of solely subvertical faults here.

The profile $68 / 83$ was situated in the westernmost part of the studied area. In the north it nearly reaches the crystalline complex exposed on the slopes of the Krušné hory Mts. The re-interpreted data from the LIH1534, LK12, LK13, LK14 and LOM1630 boreholes (Fig. 1) identified a granite porphyry dyke within the crystalline complex underlying the sedimentary sequences at the end of profile (Fig. 4). In the original seismic interpretation, the seismic manifestation of this dyke was described as a fault system inclined to the NNW in the gneiss complex. New interpretation designates radial faults as the southern margin of the Litvínov-Libkovice granite porphyry dyke, which is a continuation of the Fláje-Loučná dyke further north (Fig. 1).

An analogous case represents also the 22/81 seismic profile, situated further to the east (Fig. 5), where the HK 190 and LB-246 boreholes in the basement also reached a granite porphyry dyke. The previous interpretations of the 22/81 seismic section (Rajchl et al. 2003) disclosed only vertical tectonic structures. Our new interpretation located a probable granite porphyry dyke, marked by area of missing reflection of the seismic signal on the both its margins.

A rather complicated is the interpretation of the 21/81 profile, in particular in its $21 \mathrm{D} / 81$ segment (Fig. 6), which intersects two granite porphyry dykes at the southern margin of the Teplice rhyolite. In this seismic section, the southern part of the Litvínov-Libkovice granite porphyry dyke (borehole LB 218) was newly recorded as was a small sub-parallel granite porphyry dyke at the southwestern margin of the Teplice rhyolite 


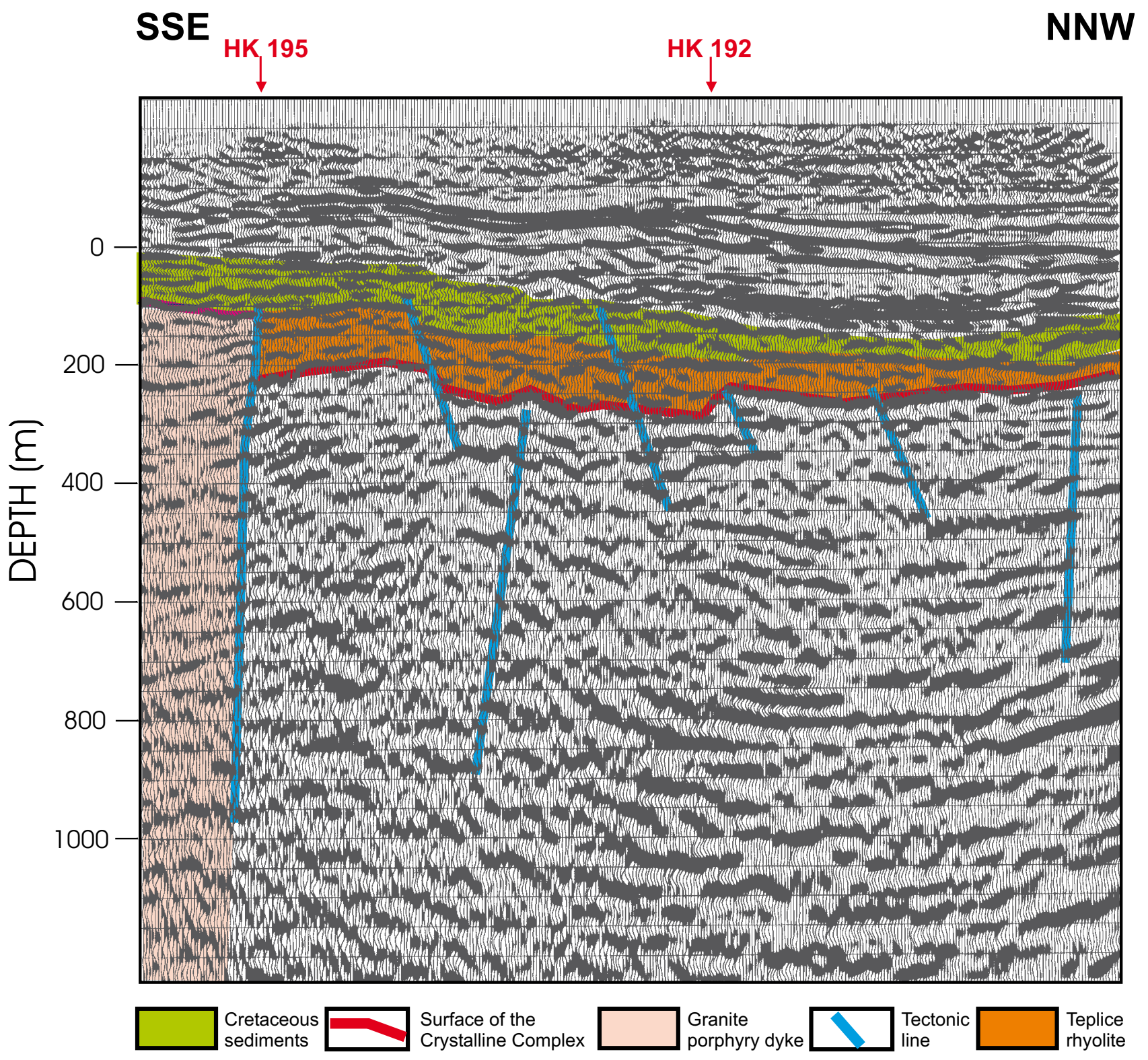

Fig. 7 Depth reflection seismic section $21 \mathrm{G} / 81$ and its interpretation.

body (HK 195). In the seismic section both these dykes are tectonically predisposed, filling the ring faults. In the northeastern part of the $21 \mathrm{D}$ profile, two interfaces were detected: the upper one corresponding to the rhyolite surface, and the lower one to the limit of the crystalline basement. The relief of the crystalline basement can be only partially determined along the whole $21 / 83$ profile. It is very indistinct and can be correlated with a segment of the $21 \mathrm{G} / 81$ profile (Fig. 7), which indicated both the relief of Teplice rhyolite and of the crystalline complex (paragneiss of the Altenberg Block). A relatively short distance between both the interfaces (c. 50 to $100 \mathrm{~m}$ ) probably caused a poor resolution of the depth indicators.

\subsection{Borehole data and $3 D$ model of the Czech part of the Altenberg-Teplice Caldera}

We made use of 1339 boreholes for the 3D modelling of the crystalline relief and 727 for the Teplice rhyolite respectively. Most of them are from the Czech Geological Survey-Geofond database. The borehole-log evaluation provided additional information regarding the depth of a hidden granite body in the eastern part of the ATC. The final 3D model of the ATC is shown in Fig. 8. The recent surface relief (Fig. 8a), denotes the actual outcrops of the ATC, where the boundaries of granite bodies, granite porphyry dykes and of the Teplice rhyolite could be mapped 


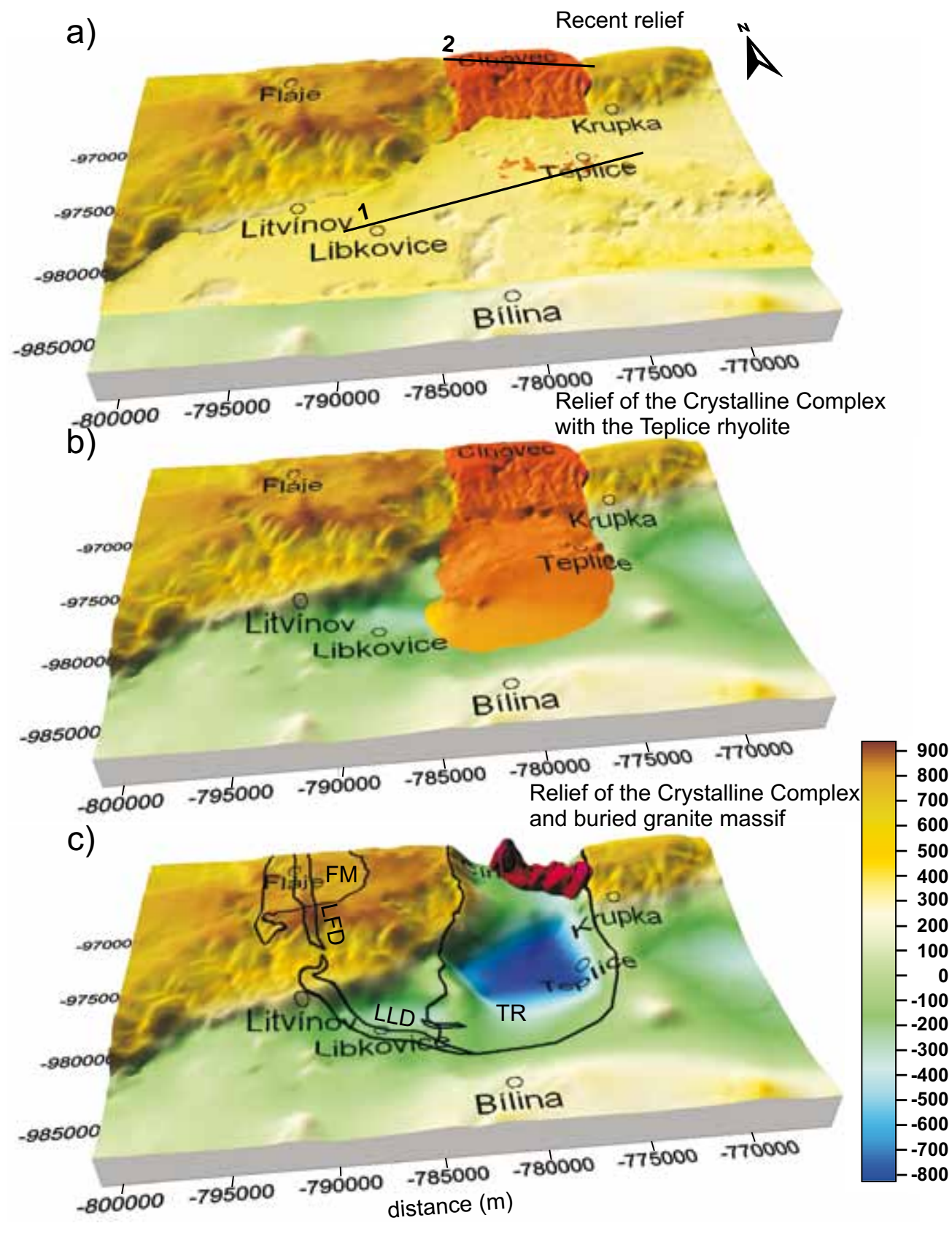

d)

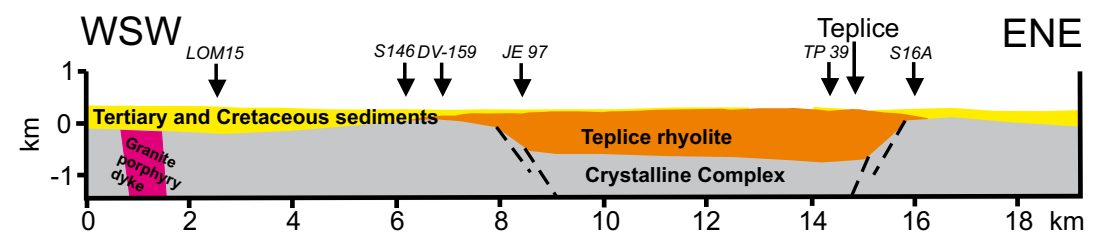

Fig. 8 A 3D model of the Czech part of the Altenberg-Teplice Caldera (x:y:z= 1:1:0.5 scaling). a - recent relief with the section position; $\mathbf{b}$ - contact plane between the crystalline complex and the Teplice rhyolite; $\mathbf{c}$ - surface of the crystalline

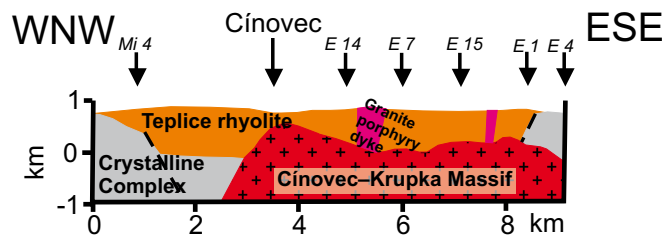
complex with the marked position of the buried granite pluton. LFD - Loučná-Fláje dyke, LLD - Litvínov-Libkovice dyke, FM - Fláje Massif, TR - Teplice rhyolite; d - Geological interpretation of the WSW-ENE Section 1 and the WNW-ESE Section 2 (in Fig. 8a). 

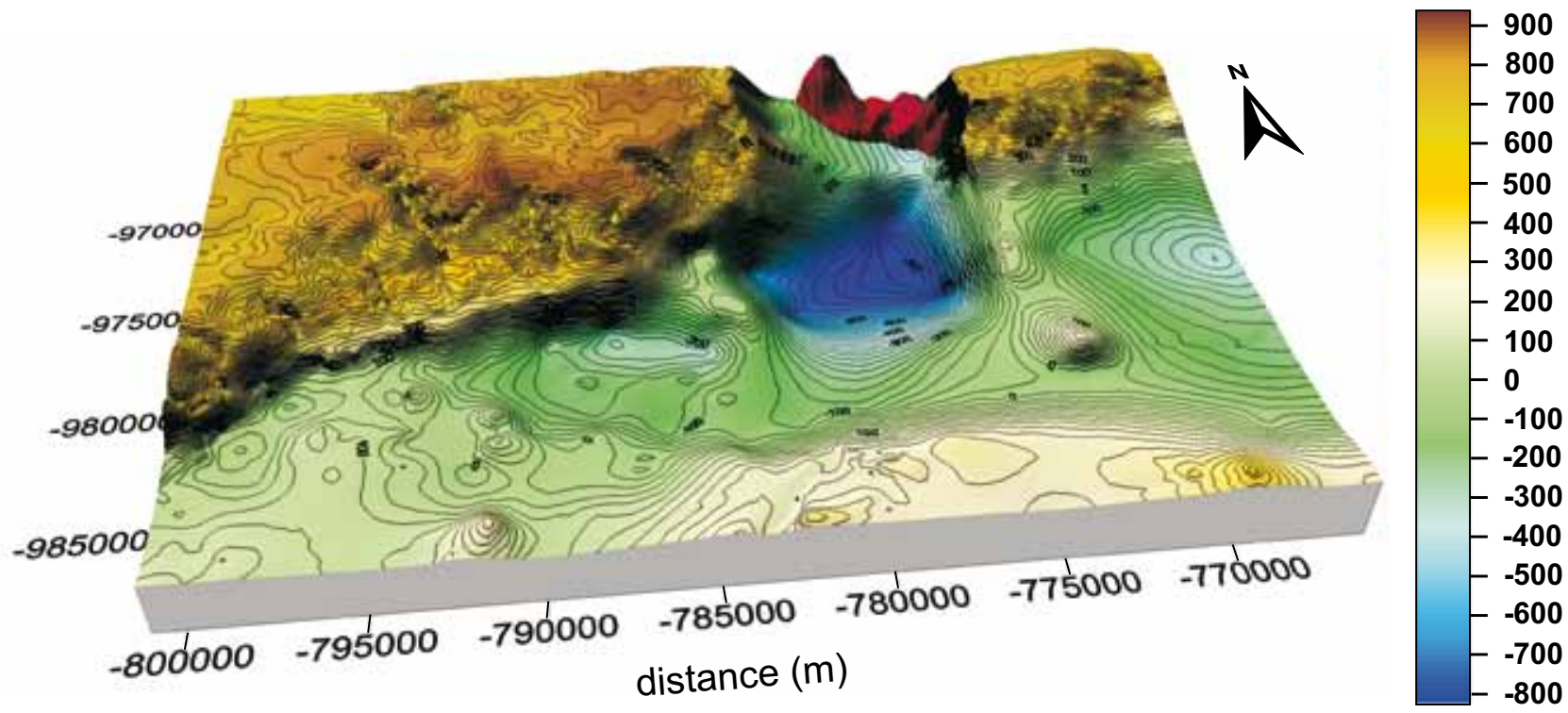

Fig. 9 Isolines of crystalline basement in the 3D model of the Czech part of the ATC (see also Fig. 8c).

in detail. The southern ATC is completely covered by Tertiary and Cretaceous sediments and only near the namesake town, the Teplice rhyolite is exposed on the Lahošt' Ridge. The 3D model without sedimentary cover (Fig. 8b) shows the Teplice rhyolite body almost reaching the southern margin of the North Bohemian Basin. Thanks to a number of boreholes drilled to the base of the Teplice rhyolite body (e.g. Mi-4, TP-39, JE-97, HK-191, HK-184), it was possible to construct an estimated 3D model (Figs 8c and 9) of the crystalline complex-Teplice rhyolite contact plane. The maximal thickness of the rhyolite body was determined in the southeastern part of the ATC, where the surface of the crystalline relief is deeper than $800 \mathrm{~m}$ below sea level. This depression is probably delimited by faults in the east and west (Fig. 8d). In the west, the crystalline block is downthrown by more than $600 \mathrm{~m}$ over a distance of $2 \mathrm{~km}$. The eastern margin of the Teplice rhyolite overlies the Altenberg Block at a moderate angle. The crystalline basement forms a ridge, whose flanks plunge steeply. In the south, in accordance with the 3D model (Fig. 9), the base of the Teplice rhyolite probably rises gradually towards the surface. In the north, the granite intrusion seen underneath the Teplice rhyolite may belong to the Cínovec-Krupka Massif exposed partly on the surface. The western boundary of this granite is not entirely clear. According to gravity data and the Mi-4 borehole, the limitation of the granite massif should be located at the northwestern margin of a gravity minimum, approximately along the Cínovec-Dubí line.

Regional gravity low in the ATC area (Fig. 10) indicates a deep source of the low-density rocks (an equivalent of the acid volcanic rocks). The regional gravity low extends beyond the marginal porphyry dykes that intruded along the ring faults, which means that the light rocks are located deeper under the caldera. This is in agreement with the seismic research (DEKORP Research Group 1994), which constrained the existence of granite bodies (sources of the Fláje and Schellerhau granite massifs, Teplice rhyolite and granite porphyry) to a depth

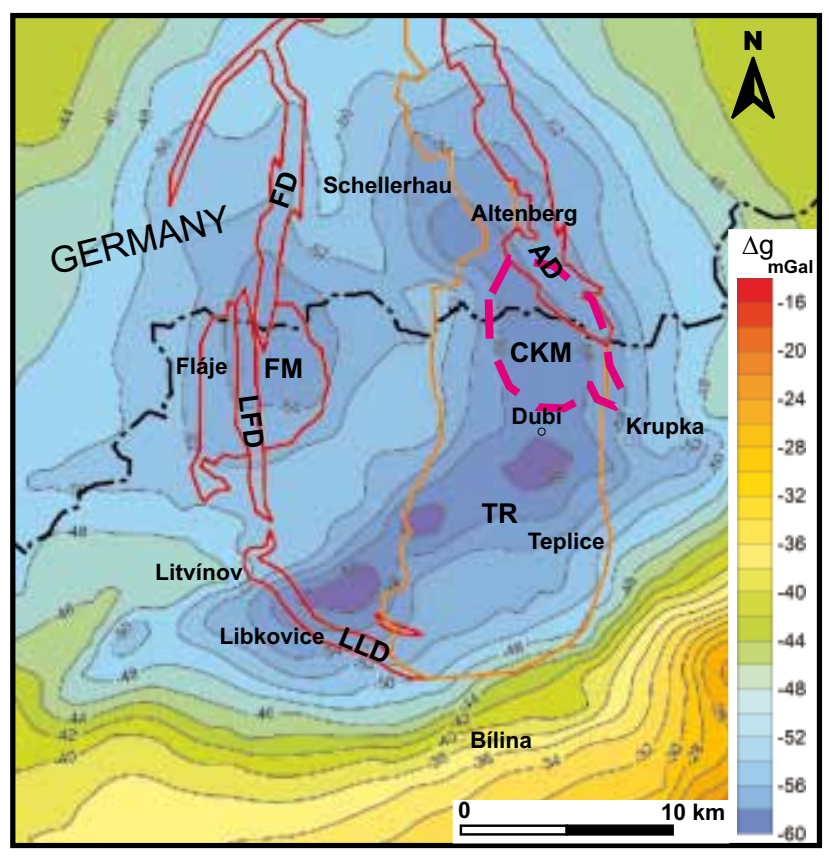

Fig. 10 Map of the Bouguer anomaly (modified after Sedlák et al. 2009) in ATC with the boundaries of the main geological units (FM - Fláje Massif, CKM - Cínovec-Krupka Massif, TR - Teplice rhyolite, AD - Altenberg dyke, FD - Frauenstein dyke, LFD - Loučná-Fláje dyke, LLD - Litvínov-Libkovice dyke). 


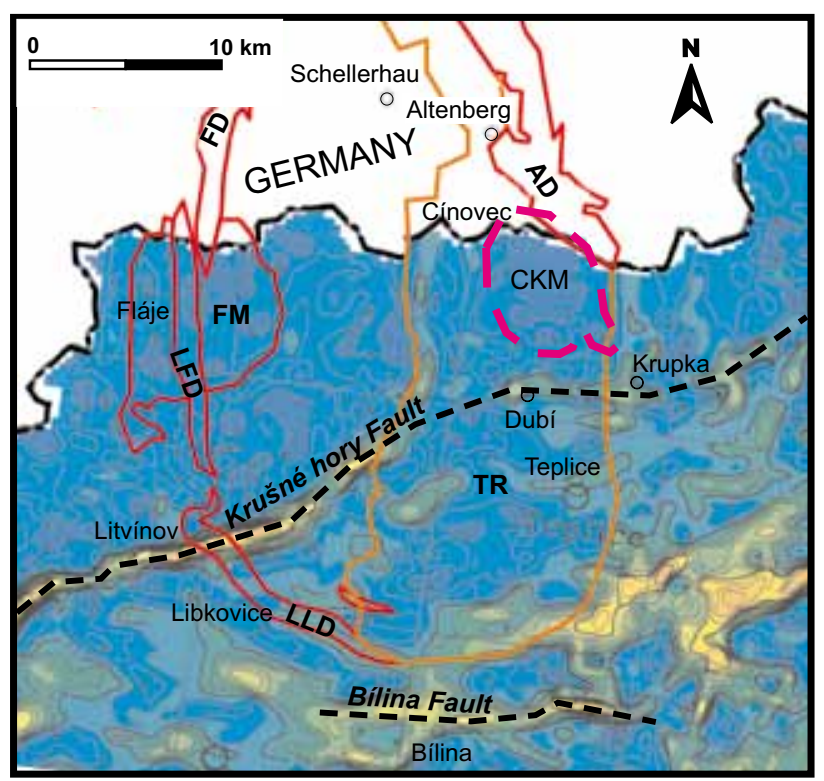

Fig. 11 Map of the horizontal gravity gradient (after Šrámek in Mlčoch ed. 2001) in the ATC with the boundaries of the main geological units (abbreviations the same as in Fig. 10).

of $c .15 \mathrm{~km}$. The Fláje granite Massif is documented as a gravity minimum (less than $-54 \mathrm{mGal}$ ) at the western margin of the caldera. In the eastern ATC, the sources of gravity low are identified as the Teplice rhyolite and the Cínovec-Krupka granite Massif. Cretaceous and Tertiary sediments of the North Bohemian Basin affect the course of geologic boundaries in the southern part of the caldera. Nevertheless, similarly to the 3D model, the down-faulted block of the crystalline complex is also reflected in gravity data. The rhyolitic rocks filling this depression at the eastern ATC generated an extensive gravity low elongated in the $\mathrm{N}-\mathrm{S}$ direction. The local minimum north of Teplice (less than $-59 \mathrm{mGal}$ ) can be interpreted as a deep source area of the Teplice rhyolite intrusion because the thickness of the sediments is relatively low (100-160 m) compared to north of Libkovice $(550 \mathrm{~m})$. The thickness of the sedimentary cover north of Teplice is $100-160 \mathrm{~m}$ and thus the sediments cannot be held responsible for the local gravity minimum (-59 m Gal).

The map of the horizontal gravity gradient (Fig.11) indicates a lateral density contrast close to Krušné hory and Bílina faults as well as at the steeply dipping contact between the Saxothuringian Crystalline Complex on the one hand, and Teplice rhyolite ( $\mathrm{N}-\mathrm{S}$ trend in the north) with the Litvínov-Libkovice porphyry dykes (NW-SE trend in the south) on the other.

\section{Discussion}

The ATC represents an ancient volcanic structure, which is not easy to reconstruct. At the beginning of the vol- canic activity, this region was probably levelled relief of the Saxothuringian Zone, which is documented by the existence of sediments deposited in shallow terrestrial depressions. The deeper part of the caldera (eroded caldera structure) of Carboniferous age is exposed on the surface and beneath the sediments. Because the ATC is large and intersects geological structures, erosion has not affected all its parts with equal intensity. Recent image of the caldera is also complicated by an asymmetrical gravitational trapdoor collapse. It is evident from the geological maps (e.g. Mlčoch ed. 1989; Hoth et al. 1995) that in each quadrant of the caldera, obvious differences in its geological structure exist, which correspond to different depth levels of the original caldera (Fig. 12). Distinct structural stages of the caldera development are seen, which do need not correspond to the depth of erosion.

The differences in the depth of erosion existed between the northern and southern parts of the caldera basement already at the onset of the volcanic activity. In the north, the relics of nappes of Early Palaeozoic rocks (phyllites and metabasites) were preserved in the hanging wall of the sheared orthogneisses (probably also nappes). The Early Palaeozoic rocks were identified from the volcanic sequences revealed in the Mi-4 borehole. Analogous situation was observed at the contact of the Saxothuringian Zone with the Teplá-Barrandian Unit (Mlčoch and Konopásek 2010). In the southern part of the caldera, the Saxothuringian Crystalline Complex is formed by paragneisses. Low-grade Early Palaeozoic rocks have not been found even in the boreholes reaching the basement of the Teplice rhyolite. The depth of the Altenberg Block downthrow can also be seen along its western margin. In the south, the Fláje-Loučná and Litvínov-Libkovice granite porphyry dykes sharply separate the paragneisses of Altenberg Block from the orthogneisses of the Catherine Dome, while in the north, the nappes of Early Palaeozoic rocks continue even beyond the caldera. The Teplice rhyolite consisting mostly of ignimbrites of the main volcanic phase reaches the maximum thickness (up to $1200 \mathrm{~m}$ ) in the southeastern quadrant of the caldera. This fact is readily apparent from the 3D model shown in Fig. 8. Older volcanic sequences have not been found, except for the dacite from the LH31 borehole (Mlčoch ed. 2001). The thickness of the ignimbrites in the northeastern quadrant is significantly lower and older volcano-sedimentary sequences are preserved in their footwall (the Schönfeld Unit). The remnants of ignimbrites occur also in the northwestern quadrant. Although the northern part of the caldera represents a "deeper" level of the volcanic apparatus (with preserved older volcano-sedimentary sequences) it does not need to correspond to a "deeper" level of erosion. The thickness of ignimbrites was probably not comparable to that in the south to start with. 

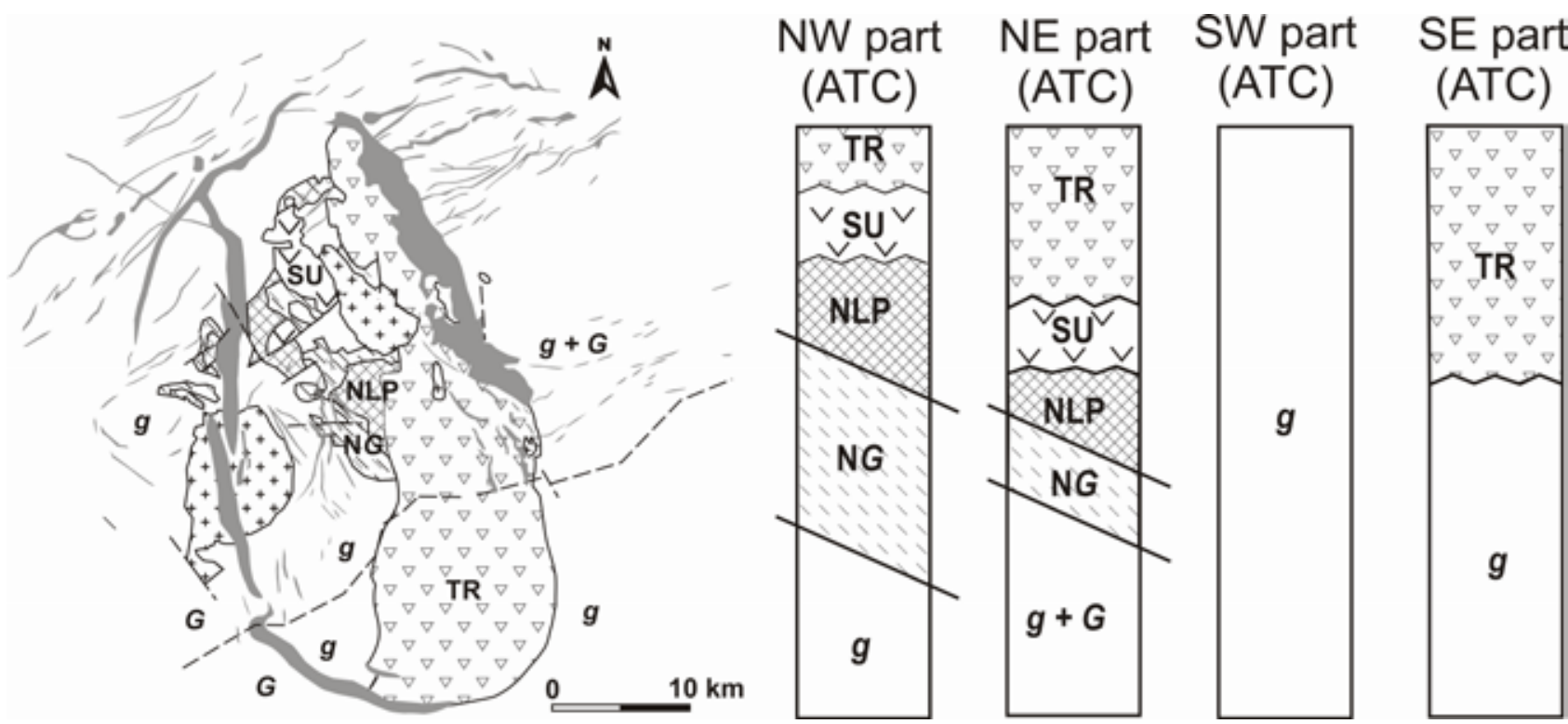

Fig. 12 Schematic distribution of the main geological units in four quadrants of the ATC (TR - Teplice rhyolite, SU - Schönfeld Unit, NLP - Lower Palaeozoic nappes, NG - orthogneiss nappes, $\mathrm{g}$ - paragneisses of the Saxothuringian Crystalline Complex, $\mathrm{G}$ - orthogneisses of the Saxothuringian Crystalline Complex).

Significant information about the caldera evolution can be inferred from the existence of granite porphyry and rhyolite dyke swarms within, and outside, the ATC. Uplift of the caldera structure is highlighted by the external radial dykes striking predominantly WSW-ENE in the middle part. Some dykes of SW-NE trend in the north run generally perpendicularly to the elongation of the caldera. The majority of these granite porphyry and rhyolitic dykes are therefore older than the gravitational collapse of the caldera. In the north, in the Sayda-Bergiesshübel dyke swarm three generations of rhyolitic dykes can be distinguished (Winter et al. 2008), some of them probably also related to a later phase of the caldera evolution. The granite porphyry dykes within the caldera plugged the faults trending approximately NNW-SSE to N-S, which had originated during the gravitational collapse. The dykes in the Altenberg Block and in the Teplice rhyolite dip to the east and are linked with a unilateral subsidence (of the eastern part) and the occurrence of the fault fissures. The ATC subsided asymmetrically bringing about a trapdoor-type collapse perceptible especially in the 3D model for the crystalline relief (Fig. 8c). The subsidence proceeded probably gradually from the west to the east as indicated by the dyke swarms. The Fláje granite Massif played a significant role in consolidation of the northwestern sector of the caldera. Moreover, it may have caused a difference in the caldera floor level of the collapsing block relative to its surroundings. The Fláje Massif was situated apparently close to the surface at the moment of the collapse (Müller and Seltmann 2002).
The final phase of the caldera subsidence gave rise to granite porphyry dykes filling the ring-faults (e.g. Altenberg, Frauenstein, Fláje-Loučná, Litvínov-Libkovice). These include the dykes in the caldera's centre (both in the Teplice rhyolite and Altenberg Block), which are subparallel with the ring faults and filled fractures generated during the caldera collapse. The Litvínov-Libkovice dyke and second small dyke at the southern rim below Tertiary and Cretaceous sediments were found in boreholes (Mlčoch 1994) and verified by a new interpretation of the seismic reflection survey (Figs 4-7).

In its western part, the Teplice rhyolite body covers the crystalline complex of the Altenberg Block and is only $30-50 \mathrm{~m}$ thick. An abrupt down-throw is found from the boreholes and it is visible in the $3 \mathrm{D}$ model (Fig. 8c) only near the centre of the caldera (1 to 2 $\mathrm{km}$ from the margin of the Teplice rhyolite). This fault could have been contemporaneous with the effusion of the Teplice rhyolite, as corroborated by the absence of any younger dykes filling this fault and intruding the rhyolite body. The down-throw reaches a depth of about $690 \mathrm{~m}$ b.s.1. (borehole JE-97), which is comparable with the maximum vertical movement in the east (TP39). The borehole data at the southeastern margin of the ATC are sufficient to detect the Teplice rhyolite body but are not adequate for the modelling of the crystalline basement surface. This is also obvious from the 3D model (moderately rising trend of the basement southwards). Lastly, a younger Cínovec-Krupka granitic intrusion occurs below the rhyolite in the north, in the mountainous part. 
Rhyolite tuffs and ignimbrites are also documented outside the ATC as distinct strata in the Permo-Carboniferous sequences of the Tharandt Caldera, as well as in the Döhlend, Brandov and Erzgebirge basins. Some relics are seen also in the basement of Cretaceous sediments at the southeastern margin of the České středohoří Mts. (Porta Bohemica). A part of them may have originated from the ATC, but possibly also from other volcanic centres.

\section{Conclusions}

The presented 3D digital model based on borehole and geophysical data enables, together with the current geological, geochemical and petrological data, new interpretation of the Altenberg-Teplice Caldera (ATC) evolution. Seismic reflection profiles 21/83, 22/83 a 68/83 were used to determine the depth of the crystalline complex and the Teplice rhyolite below the Cretaceous and Tertiary sediments. The Teplice rhyolite relief and occurrence of granite porphyry dykes were identified by the new interpretation. Moreover, seismic data verified the position of the Litvínov-Libkovice granite porphyry dyke in the basement of the Most Basin.

The geology of the crystalline relief revealed a different level of erosion between the northern and southern parts of the ATC. Based on their relation to the ATC, several generations of granite porphyry and rhyolite dykes can be distinguished. The oldest would be the upliftrelated dykes trending perpendicularly to the caldera's elongation, especially in its middle part. The gravity collapse was accompanied by the emplacement of the youngest ring dykes, which had bounded the caldera area, and by additional sub-parallel dykes inside the caldera or in its vicinity.

The geometry of the ATC correlates with the asymmetrical trapdoor gravity collapse event, whereby the western margin was influenced by the existence of the Fláje Massif. The 3D model of the ATC indicates a sunken block of the Altenberg Crystalline Complex limited by faults from the east and the west. Their origin was probably contemporaneous with the main volcanic phase of the Teplice rhyolite effusion. The down-throw was enormous in the southeastern part, as shown by the maximal thickness of the rhyolite body near Teplice (over $1000 \mathrm{~m}$ ).

Acknowledgements. This research was financially supported by Ministry of Education, Youth and Sports of the Czech Republic through the Research Centre 1M0554 "Advanced Remedial Technologies and Processes" and project No A300460602 of the Grant Agency of the Academy of Sciences of the Czech Republic. Thanks are due to the reviewers R. Seltmann, M. Lapp and handling editor M. Štemprok for their comments and suggestions.

\section{References}

BeneK R (1991) Aspekte einer Volumenbilanz paläovulkanischer Förderprodukte - Beispiel Teplice Rhyolith (Ostdeutschland). Z geol Wiss 19: 379-389

BReITER K (1997) The Teplice rhyolite (Krušné hory Mts., Czech Republic) - chemical evidence of a multiply exhausted stratified magma chamber. Bull Czech Geol Surv 72: 205-213

Breiter K, NovÁk JK, Chlupáčová M (2001) Chemical evolution of volcanic rocks in the Altenberg-Teplice caldera (Eastern Krušné hory Mts., Czech Republic, Germany). Geolines 13: 17-22

CHRT J, MALÁsek F (1984) The buried relief of the Rudohoří (Erzgebirge) granites between Cínovec and Krupka. Geol Průzk 26: 305-309 (in Czech)

Cole J W, Milner DM, Spinks KD (2005) Calderas and caldera structures: a review. Earth Sci Rev 69: 1-26

DEKORP RESEARCh Group (1994) The deep reflection seismic profiles DEKORP 3/MVE-90. Z geol Wiss 22: 627-824

FÖRSTER H J, ROMER RL (2010) Carboniferous magmatism. In: Linnemann U, Romer RL (eds) Pre-Mesozoic Geology of Saxo-Thuringia from the Cadomian Active Margin to the Variscan Orogen. Schweizerbart, Stuttgart, pp 287-308

Holohan EP, Benjamin WV, Troll VR (2008) Analogue models of caldera collapse in strike-slip tectonic regimes. Bull Volcanol 70:773-796

Holub FV (1980) Petrography of the samples from the Deep Borehole Le -127 (B) In: Final Report of the project Barbora II. Part F. Final Report of Geoindustria. Unpublished manuscript, Czech Geological Survey - Geofond, Prague, pp 1-81 (in Czech)

Hoth K, Wasternack J, Berger H J, Breiter K, Mlčoch B, SchovÁnek P (1995) Geologische Karte Erzgebirge/ Vogtland $1: 100$ 000. Sächsisches Landesamt für Umwelt und Geologie, Freiberg

Jihlavec F, Chudomel J, Jakeš O, Kadleč́́ J, Novák J, Piller S (1983) Final Report - Seismic Survey in the SE part of the Most Basin in 1981-1982, Barbora-Maxim Gorkij Profile. Unpublished manuscript, Geofyzika, Brno, pp 1-30 (in Czech)

Jihlavec F, Chudomel J, Filková V, Hikl V, Horová M, JAKEŠ O, NovÁK J (1984) Seismic Survey in the KOH-INOOR Opet Pit Mine in the years 1983-84. Unpublished manuscript, Geofyzika, Brno, pp 1-29 (in Czech)

JIRÁNEK J ed (1991) Geological map ČSSR $1: 25$ 000, sheet 02-322 Krupka. Czech Geological Survey, Prague

JiRÁNeK J, KŘíbek B, MLČoch B, ProcházKa J, SchováneK P (1987) Complex Geological Study of the Teplice Rhyolite. Final Report. Unpublished manuscript, Czech Geological Survey, Prague, pp 1-114 (in Czech) 
Lange H, Tischendorf G, Pälchen W, Klemm I, Ossenkopf E (1972) Fortschritte der Metallogenic im Erzgebirge. B. Zur Petrographic und Geochemie der Granite des Erzgebirges. Geologie 21, 4/5, pp 491-520

MaLÁsé F ed (1987) Report on Search of the Granite Elevation in the Eastern Part of the Krušné hory Mts. Mineral Deposit: Sn-W. Unpublished manuscript, Czech Geological Survey - Geofond, Prague, pp 1-56, 164 appendix folders (in Czech)

MLČOCH B ed (1989) Geological map ČSSR 1: 25 000, sheet 02-314 Litvínov. Czech Geological Survey, Prague

MLČOCH B (1994) The geological structure of the crystalline basement below the North Bohemian brown coal Basin. KTB Report 94(3): 39-46. Niedersächsisches Landesamt für Bodenforschung, Hannover

MLČOCH B ed (2001) Research on the Crystalline Basement of Doupovské hory Mts. and Their Vicinity. Final Report. VAV 631/1/00. Unpublished manuscript, Czech Geological Survey, Prague, pp 1-120 (in Czech)

MLČOCH B (2003) Character of the contact between the Saxothuringian and Teplá-Barrandian Unit. Geolines 16: 75

MlČoch B, KonopáseK J (2010) Pre-Late Carboniferous geology along the contact of the Saxothuringian and Teplá-Barrandian zones in the area covered by younger sediments and volcanics (western Bohemian Massif, Czech Republic). J Geosci 55: 81-94

Moesta G (1928) Brüche und Porphyreffusionen im östlichen Erzgebirge. Z Dtsch geol Gesell 80: 343-408

Müller A, Seltmann R (2002) Plagioclase-mantled Kfeldspar in the Carboniferous porphyric microgranite of Altenberg-Frauenstein, Eastern Erzgebirge/Krušné Hory. Bull Geol Soc Finland 74: 53-79

Müller A, Breiter K, Seltmann R, Pécskay Z (2005) Quartz and feldspar zoning in the eastern Erzgebirge Volcano-Plutonic Complex (Germany, Czech Republic): evidence of multiple magma mixing. Lithos 80: 201-227

Novák JK, Chrt J, Malásek F (1991) The hidden granite relief and its significance for prospection (as an example of the eastern part of the Krušné hory Mts). In: KUKAL (ed) Proceedings of the $1^{\text {st }}$ International Conference on the Bohemian Massif. Czech Geological Survey, Prague, pp 205-207
Rajchl M, UličNÝ D, Hubatka F (2003) Syn- and postsedimentary tectonics of the Most Basin (Ohře Rift, Czech Republic); insights from reflection-seismic data. Geolines 16: 86

Romer RL, Thomas R, Stein HJ, Rhede D (2007) Dating multiply overprinted Sn-mineralized granites - examples from the Erzgebirge, Germany. Mineral Depos 42: 337-359

Schovánek P ed, Adamová M, Breiter K, Burda J, Cajz V, ElzNic A, Fürych V, GodÁny J, KoŘán V, Manová M, Nekovařík Č, Š́alanský K, Šebesta J (2004) Explanatory text of Geological map of Czech Republic to sheets 02-321 Dubí and 02-143 Cínovec. Czech Geological Survey, Prague, pp 1-84 (in Czech)

Sedlák J, Gnojek I, Zabadal S, Scheibe R, Zabadal $\mathrm{S}$ (2009) Gravity response of igneous rocks in the northwestern part of the Bohemian Massif. J Geosci 54: 325-342

Seltmann R, Schilka W (1995) Late-Variscan crustal evolution in the Altenberg-Teplice caldera. Evidence from new geochemical and geochronological data. Terra Nostra 7/95: 120-124.

Spinks KD, Acoccella V, Cole JW, Bassett KN (2005) Structural control of volcanism and caldera development on the transtensional Taupo Volcanic Zone, New Zealand. J Volcanol Geotherm Res 144: 7-22

ŠTemprok M, Holub FV, NovÁk JK (2003) Multiple magmatic pulses of the Eastern Volcano-Plutonic Complex, Krušné hory/Erzgebirge Batholith, and their phosphorus contents. Bull Geosci 78: 277-296

Troll VR, Walter TR, Schmincke HU (2002) Cyclic caldera collapse: piston or piecemeal subsidence? Field and experimental evidence. Geology 30: 135-138

Walter T R, Troll VR (2001) Formation of caldera periphery faults: an experimental study. Bull Volcanol 63: 191-203

Winter C, Breitkreuz C, Lapp M (2008) Textural analysis of Late Palaeozoic coherent-pyroclastic rhyolitic dyke system near Burkerdorf(Erzgebirge, Saxony, Germany). In: Thomson K, Petford N (eds) Structure and Emplacement of High-Level Magmatic Systems. Geological Society of London Special Publications 302: 199-221 
